\title{
Location and ultrastructure of spotted fever rickettsiae in nymphal
}

\section{Haemaphysalis hystricis ticks}

\author{
Yasuhiro YANO $^{1 *}$, Nobuhiro TAKADA ${ }^{1}$, Hiromi FUJITA ${ }^{2}$, Mutsuyo GOKUDEN $^{3}$ and \\ Shuji ANDO 4 \\ ${ }^{1}$ Faculty of Medical Sciences, University of Fukui, Eiheji Fukui 910-1193 Japan \\ ${ }^{2}$ Mahara Institute of Medical Acarology, Anan Tokushima 799-1510 Japan \\ ${ }^{3}$ Kagoshima Prefectural Institute for Environmental Research and Public Health, Kagoshima 892- \\ 0836 Japan \\ ${ }^{4}$ National Institute of Infectious Diseases, Tokyo 162-8640 Japan
}

\begin{abstract}
The Haemaphysalis hystricis ticks we collected contained rod-shaped rickettsiae (length, $1.3 \mu \mathrm{m}$; diameter, $0.3 \mu \mathrm{m}$ ) in midgut epithelial cells, rectal sac cells, muscle cells surrounding trachea, cells of the central nervous system, and granular cells of the salivary glands. These microorganisms, which were defined as Rickettsia japonica by PCR analysis, existed freely in the cytoplasm of the cells and were surrounded by an electron-lucent (halo) zone. Nuclear localization and proliferation of the rickettsia were present in salivary gland cells. The rickettsial species we evaluated also demonstrate trans-stadial transmission because we used nymphal ticks, which molted from engorged larvae. This report is the first to describe the location and ultrastructure of spotted fever rickettsiae in $H$. hystricis ticks.
\end{abstract}

Key words: ultrastructure, spotted fever, rickettsiae, Haemaphysalis hystricis

\section{INTRODUCTION}

During a epidemiologic survey of Japanese spotted fever in July 2011 at Fukuoka City, Japan, 20 engorged larval Haemaphysalis hystricis ticks were collected from an Apodemus speciosus rodent. These ticks molted into nymphs under the laboratory conditions. Ten of the 20 ticks collected were emulsified and individually inoculated into L-929 cultured cells (for 3 wk at $33^{\circ} \mathrm{C}$ ). Rickettsiae were isolated from the ticks according to the methods described in our previous report (Takada, et al., 1994). PCR analysis (Gokuden, et al., 2011) identified these rickettsiae as Rickettsia japonica, a causative agent of Japanese spotted fever. The remaining 10 ticks were used to evaluate the location and ultrastructure of the rickettsiae in various tick organs.

Tetsuo Gotoh and DeMar TAYLOR (eds.), Acarology XIV: Proceedings of the International Congress. Journal of Acarological Society of Japan 25 (Suppl. 1): 1-192.

* Corresponding author: tel: +81 77661 8331, e-mail: yhyano@u-fukui.ac.jp

DOI: 10.2300/acari.25.Suppl_185 


\section{MATERIALS AND METHODS}

Tick internal organs including midgut, rectal sac, trachea, central nervous system, and salivary gland were dissected in cold $3 \%$ glutaraldehyde in $0.1 \mathrm{M}$ sodium cacodylate buffer ( $\mathrm{pH} 7.4$ ), fixed for $6 \mathrm{~h}$, and washed in fresh buffer. The tissues were postfixed for $3.5 \mathrm{~h}$ in $1 \% \mathrm{OsO}_{4}$ in $0.1 \mathrm{M}$ sodium cacodylate buffer, dehydrated in an acetone series, and embedded in epoxy resin. Thin sections (about $70 \mathrm{~nm}$ ) were cut on a microtome, by using a diamond knife, and doubly stained with uranyl acetate and lead acetate before examination in an electron microscope $(75 \mathrm{kV}$, model H-7650, Hitachi High-Technologies Corp., Tokyo).

\section{RESULTS AND DISCUSSION}

The $H$. hystricis ticks we collected contained rod-shaped rickettsiae (length, $1.3 \mu \mathrm{m}$; diameter, $0.3 \mu \mathrm{m}$ ) in midgut epithelial cells (Fig. 1), rectal sac cells (Fig. 2), muscle cells surrounding trachea (Fig. 3), cells of the central nervous system (Fig. 4), and granular cells of the salivary glands (Figs. 5 and 6). These microorganisms, which were defined as $R$. japonica by PCR analysis (Gokuden, et al., 2011), existed freely in the cytoplasm of the cells and were surrounded by an electron-lucent (halo) zone (Fig. 5, inset). The cell walls of the rickettsiae exhibited a welldefined structure with the inner electron-dense layer thicker than its outer layer (Fig. 5, inset). Nuclear localization and proliferation of the rickettsia were present in salivary gland cells (Fig. 6). The ultrastructural features of the isolated rickettsiae resembled those of rickettsiae in the

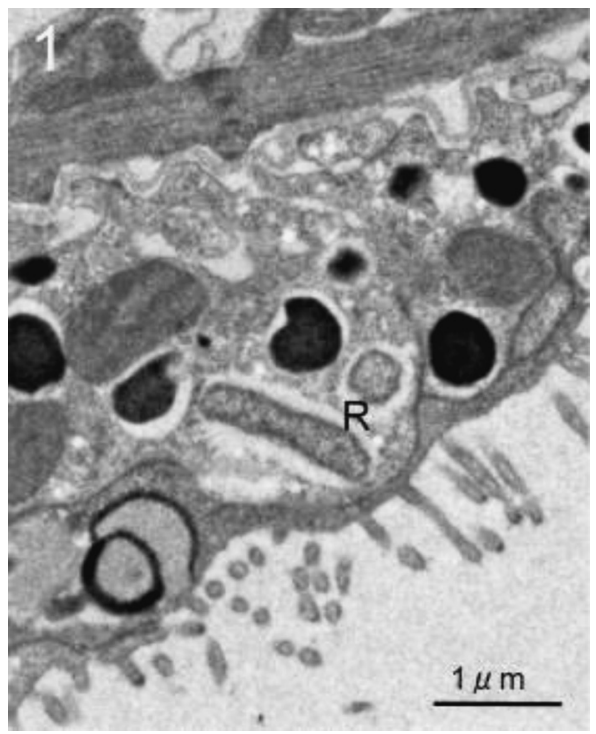

Fig. 1 Cross section and longitudinal section of rickettsiae (R) in a midgut epithelial cell.

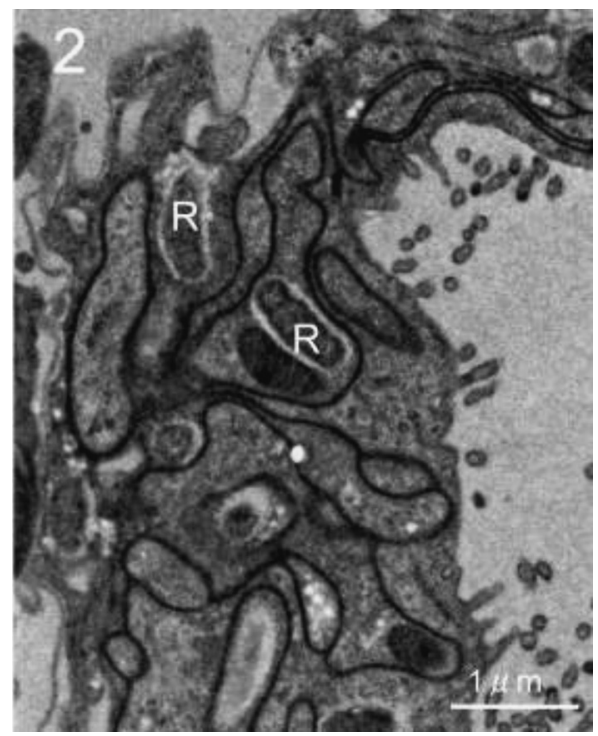

Fig. 2 Rickettsiae (R) in a rectal sac cell. 


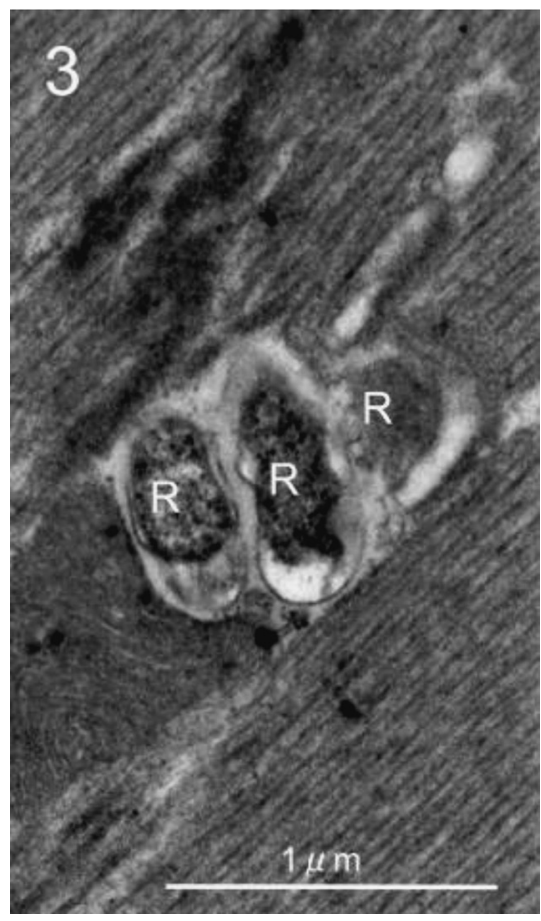

Fig. 3 Rickettsiae (R) in a muscle cell along the trachea.

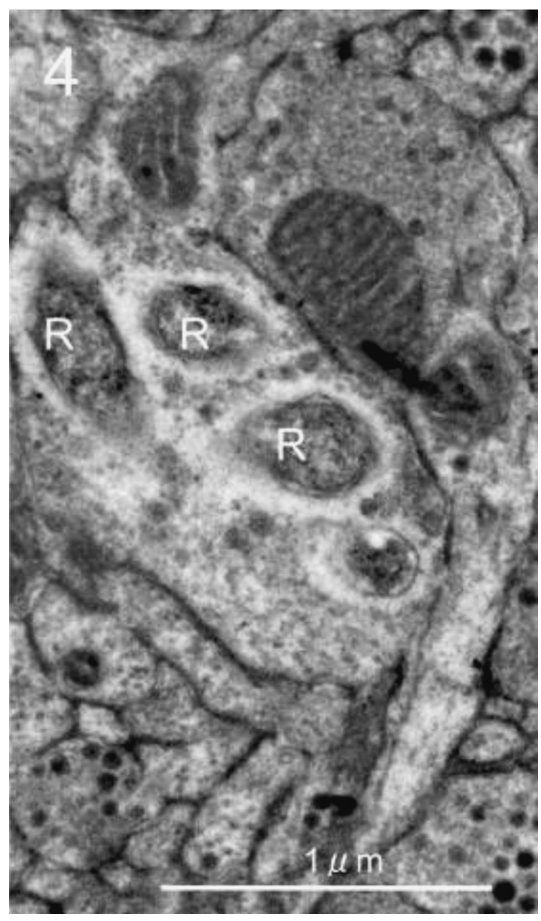

Fig. 4 Rickettsiae (R) in a central nervous system cell.

spotted fever group (Silverman et al., 1978; Yano et al., 1993; Yano et al., 2004). Specifically, the current rickettsiae were found in the cells of every organ evaluated. A similar distribution was noted for the spotted fever group rickettsia (subsequently identified as Rickettsia tamurae) in Amblyomma testudinarium tick larvae (Yano et al., 2000). The presence of rickettsiae in the salivary gland suggests that they are transmitted with salivary secretions to hosts during feeding by $H$. hystricis ticks. Nymphal $H$. hystricis ticks are known to bite humans, and H. hystricis is thought to be the most important vector of $R$. japonica to humans (Yamauchi et al., 2009).

Furthermore, the rickettsial species we evaluated also demonstrate trans-stadial transmission because we used nymphal ticks, which molted from engorged larvae. This report is the first to describe the location and ultrastructure of spotted fever rickettsiae in $H$. hystricis ticks. 


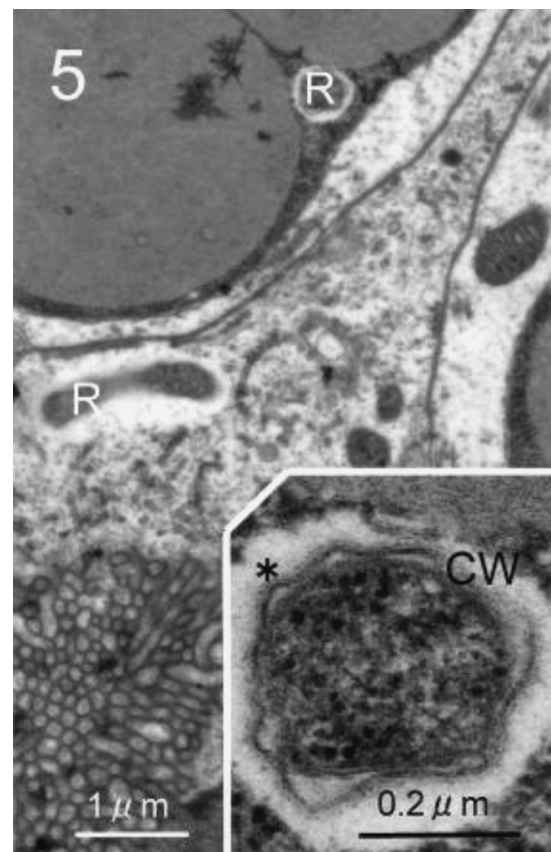

Fig. 5 Rickettsiae (R) in a salivary gland granular cell. The inset shows a cross section of a rickettsia. CW, cell wall; *, halo zone

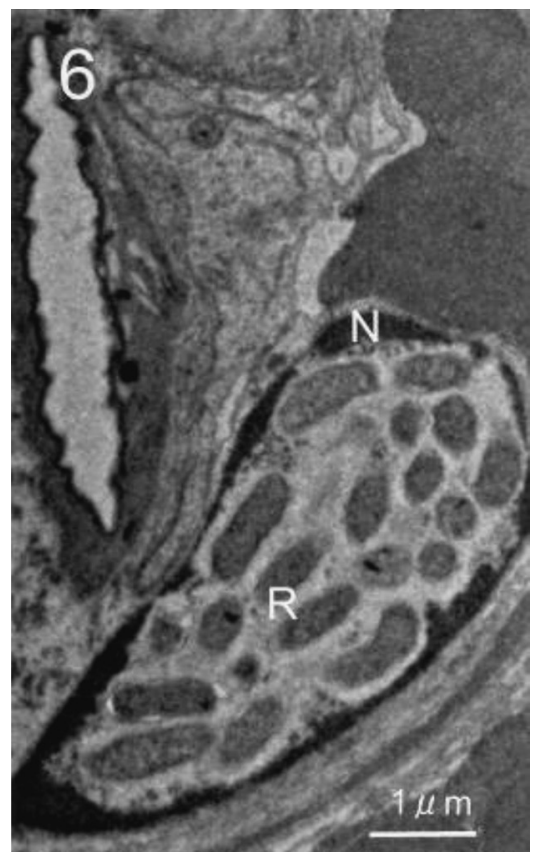

Fig. 6 Proliferating rickettsiae (R) in the nucleus $(\mathrm{N})$ of a salivary gland granular cell.

\section{REFERENCES}

Gokuden, M., S. Yamamoto, S. Ando, T. Kitano, K. Taira, S. Okano, M. Miyadai, K. Kajiyama, T. Ishibashi, A. Takano, T. Kadosaka, M. Takahashi, H. Fujita and N. Takada (2011) Trend of rickettsial diseases in Kyushu District. Annual Report of Ohara General Hospital, 51: 80. (in Japanese)

Silverman, D. J. and C. L. Wisseman, Jr. (1978) Comparative ultrastructural study on the cell envelopes of Rickettsia prowazekii, Rickettsia rickettsii, and Rickettsia tsutsugamushi. Infection and Immunity, 21: 1020-1023.

Takada, N., H. Fujita, Y. Yano, Y. Tsuboi and F. Mahara (1994) First isolation of a rickettsia closely related to Japanese spotted fever pathogen from a tick in Japan. Journal of Medical Entomology, 31: 183-185

Yamauchi, T., Y. Shimazu and H. Mizuta (2009) A case of human tick bite by a nymphal tick, Haemaphysalis hystricis (Acari: Ixodidae), in Japan. Medical Entomology and Zoology, 60: 135-137.

Yano, Y., H. Fujita and N. Takada (2004) Ultrastructure of a Japanese rickettsial strain genetically identified as Rickettsia helvetica which was originally found in Europe. Microbiology and Immunology, 48: 535-539.

Yano, Y., N. Takada and H. Fujita (1993) Ultrastructure of spotted fever rickettsialike microorganisms observed in tissues of Dermacentor taiwanensis (Acari:Ixodidae). Journal of Medical Entomology, 30: 579-585.

Yano, Y., N. Takada and H. Fujita (2000) Ultrastructure of spotted fever group rickettsae in tissues of larval Amblyomma testudinarium (Acari: Ixodidae). Journal of Acarological Society of Japan, 9: 181-184. 